Gut, 1972, 13, 379-384

\title{
An immunofluorescent study of the distribution of immunoglobulin-containing cells in the normal and the inflamed human gall bladder
}

\author{
F. H. Y. GREEN AND H. FOX \\ From the Department of Pathology, University of Manchester
}

SUMMARY Immunoglobulin-containing cells are present in the normal human gall bladder but they are much less numerous in this site than in the normal intestine. IgA-containing cells predominate in the mucosa but in the muscle layer IgM cells are the more numerous. In both acute and chronic inflammation of the gall bladder there is a marked increase in the number of immunoglobulincontaining cells. In all but the most severe cases of inflammation it is those cells containing IgA which show the greatest increase in numbers, but in severe cases there is a disproportionate rise in the number of IgG- and IgM-containing cells, these latter being possibly derived from the blood. IgA cannot be demonstrated in the epithelial cells of the gall bladder and positive evidence of secretion into the bile of locally produced immunoglobulin is lacking.

It is suggested that the concentration of IgA normally present in bile is such that, irrespective of local production, some is derived from the serum or the intestine.

The existence of a local secretory immune system that is independent of that responsible for the formation of circulating antibodies is now well established. The outstanding feature of this system is the predominance of $\operatorname{IgA}$ antibodies which are secreted into many external secretions by plasma cells indigenous to the secretory organ (Tomasi and DeCoteau, 1970). This system has been extensively studied in the respiratory and intestinal tracts (Crabbé, Carbonara, and Heremans, 1965; Crabbé and Heremans, 1966; Brandtzaeg, Fjellanger, and Gjeruldsen, 1967; Rossen, Morgan, Hsu, Butler, and Rose, 1968) but little attention has been paid to its activity in the biliary system. It has been stated that IgA and IgG are present in bile in concentrations similar to those found in the small intestinal contents (Tomasi, 1970) but detailed studies of immunoglobulin-containing cells in the human gall bladder have not been reported, and it is thus not clear whether biliary antibodies are derived from the serum, the intestine, or from the gall bladder itself; not is it known whether a local immune system plays any role in biliary tract disease.

We report here a study of the local immunoglobulin synthesizing systems in the human gall bladder.

Received for publication 29 February 1972.

\section{Materials and Methods}

\section{SPECIMENS}

Thirty-five gall bladders were obtained from patients undergoing cholecystectomy. The specimens were received immediately after surgical removal and blocks were cut circumferentially from the body of the gall bladder away from the hepatic bed, a pilot study having shown that this area was representative for the purposes of this study. The blocks were snap frozen in isopentane, cooled by solid carbon dioxide, and serial sections were cut in an open-top cryostat at a thickness of $5 \mu$. These sections, when on slides, could be stored at $-20^{\circ} \mathrm{C}$ for up to two weeks.

\section{ANTISERA}

Specific freeze-dried antisera prepared in swine against human $\operatorname{IgA}$ and $\operatorname{IgG}$ and conjugated with fluorescein isothiocyanate were obtained from Nordic Pharmaceuticals and Diagnostics. Similar non-conjugated antisera were also obtained as controls. These antisera had been rendered monospecific by absorption techniques and their specificity confirmed, both before and after conjugation, by immunoelectrophoresis. Before use the antisera were reconstituted with distilled water and diluted 1 in 10 with isotonic saline. 


\section{STAINING}

Sections were fixed in acetone for one to two minutes and then washed in two successive baths of buffered saline containing $0.02 \mathrm{M}$ Sorensen buffer at $p \mathrm{H} \mathbf{7 \cdot 2}$. Excess saline was removed with blotting paper and the sections were covered with two drops of the diluted antisera; these were than incubated in a moist chamber at room temperature for $\mathbf{4 0}$ minutes after which the excess dye was removed by gentle dipping in successive baths of buffered saline for 15 minutes. The slides were mounted in phosphatebuffered glycerine at $p \mathrm{H} 7 \cdot 2$. A serial section was stained by haematoxylin and eosin.

\section{CONTROLS}

Unstained sections mounted in buffered glycerine were used for the estimation of autofluorescence. Specificity of the staining of each conjugate was confirmed by a block technique in which sections were incubated with, as above, unconjugated swine antihuman IgA, IgG, or IgM; after washing in buffered saline the appropriate conjugated antiglobulin was added for a further 20 minutes.

\section{MICROSCOPY}

For fluorescence microscopy a Leitz Ortholux microscope fitted with a Phillips C.S. ultraviolet lamp, a GB12 excitor filter, and blue absorbent barrier filters was used. With this combination the fluorescent areas appeared white against a black background. The microscope was fitted with a Leitz Orthomat camera with an automatic exposure meter and photographs were taken using Pan Plus $x$ film.

The sections were initially examined under low power $(\times 40)$ to gain an impression of the general distribution of fluorescent cells. Fields were then selected that appeared to be representative of the whole section and six high-power $(\times 100)$ fields were selected for fluorescent cell counts, three of these being in the mucosa and three in the muscle layer. The number of fluorescent cells in a specifically marked area of each field was counted and at all times cells were only considered to be specifically fluorescent if previous blocking by specific unconjugated antisera completely abolished their fluorescence. The site of each field examined was recorded by a stage Verner scale and the sections were subsequently stained with haematoxylin and eosin and examined under normal light.

\section{DENSITY ESTIMATIONS}

The results obtained from fluorescent cell counts were converted into cell densities per cubic millimetre using the following formula (Elias, Hennig, and Elias, 1961):

$\mathrm{Na}=\frac{\mathrm{nA}}{\mathrm{A}(\mathrm{D}+\mathrm{T})}$

where $\mathrm{Nv}=$ mean number of cells per cubic $\mathrm{mm}$ $\mathrm{nA}=$ mean number of cells per known area

$A=$ area examined (at the magnification employed this was $0.0748 \mathrm{sq} \mathrm{mm}$ )

$\mathrm{D}=$ mean diameter of fluorescent cells $(10 \mu)$

$\mathrm{T}=$ thickness of section $(5 \mu)$.

\section{Results}

\section{LIGHT MICROSCOPY}

Of the $\mathbf{3 5}$ gall bladders, three were considered to be morphologically normal, two to be acutely inflamed, and 30 to show chronic non-specific inflammation, this being classed as mild in 16 , as moderately severe in eight, and as severe in six.

\section{FLUORESCENT MICROSCOPY}

Immunoglobulin-containing cells (Table 1)

Specifically fluorescent cells were seen in all the gall

\begin{tabular}{|c|c|c|c|c|c|c|}
\hline \multirow[t]{3}{*}{ Gall Bladder } & \multicolumn{6}{|c|}{ Population Density } \\
\hline & \multicolumn{3}{|l|}{ Mucosa } & \multicolumn{3}{|c|}{ Muscle Coat } \\
\hline & IgA Cells & IgG Cells & IgM Cells & IgA Cells & IgG Cells & IgM Cells \\
\hline $\begin{array}{l}\text { Normal } \\
\text { Mild chronic inflammation } \\
\text { Moderate chronic } \\
\text { inflammation } \\
\text { Severe chronic inflammation } \\
\text { Acute inflammation }\end{array}$ & $\begin{array}{l}2833 \\
8687 \\
( \pm 3420) \\
22937 \\
( \pm 7164) \\
48625 \\
( \pm 16383) \\
17500\end{array}$ & $\begin{array}{l}666 \\
1734 \\
( \pm 994) \\
3093 \\
( \pm 1568) \\
14666 \\
( \pm 6725) \\
2875\end{array}$ & $\begin{array}{l}1666 \\
3125 \\
( \pm 1264) \\
5000 \\
( \pm 1899) \\
22725 \\
( \pm 8480) \\
1500\end{array}$ & $\begin{array}{l}333 \\
2375 \\
( \pm 1146) \\
6375 \\
( \pm 2197) \\
9675 \\
( \pm 4036) \\
3375\end{array}$ & $\begin{array}{l}917 \\
3156 \\
( \pm 1445) \\
10437 \\
( \pm 3724) \\
18540 \\
( \pm 7095) \\
15000\end{array}$ & $\begin{array}{l}3500 \\
3796 \\
( \pm 1645) \\
11156 \\
( \pm 4596) \\
26958 \\
( \pm 11752) \\
21875\end{array}$ \\
\hline
\end{tabular}

Table I Mean values of the populatian densities of plasma cells containing $\operatorname{IgA}, \operatorname{IgG}$, and $\operatorname{IgM}$ in normal and abnormal gall bladders ${ }^{1}$

'Standard deviations are not included for those groups including less than six gall bladders.

'The figures denote the mean numbers of specifically fluorescent cells per cubic millimetre of interstitial tissue and are derived from three cell counts in each gall bladder within the category. 
bladders examined and on subsequent light microscopy nearly all of these were seen to be either plasma cells or large lymphocytes. In some cases nonspecific fluorescence of eosinophils proved troublesome but these cells always showed a less brilliant fluorescence than did the specific immunoglobulincontaining cells.

In all specimens $\operatorname{Ig} \mathrm{A}$ was the predominant immunoglobulin in the mucosa of the gall bladder, the cells containing this immunoglobulin being the most numerous in the basal area of the lamina propria. In the normal organ the number of mucosal cells containing IgA was low (Fig. 1), and it was not uncommon for such cells to be absent from many fields. In the muscle layer of the normal gall bladder cells containing IgM were predominant and were usually adjacent to small blood vessels.

In cases of both acute or chronic inflammation there was a marked increase of the number of IgAcontaining cells in the mucosa (Fig. 2), the extent of this increase being directly proportional to the severity of the inflammatory process. In chronic cholecystitis the number of mucosal cells containing IgA and IgM also rose; in mild or moderately severe cases the relative increase in the number of such cells was less than that in the number of $\operatorname{IgA}$-containing cells but in severely inflamed cases the relative proportion of IgG- and IgM-containing cells increased (Table II).

The number of cells containing IgG and IgM in the muscle layer also rose fairly markedly in cases of chronic inflammation; the number of IgA-containing cells in the muscle layer also rose in chronic inflammation but in any given gall bladder there were never as many of these cells in this site as there were in the mucosa. The IgG- and IgM-containing cells in the muscle layer tended to be clustered around the blood vessels, but where Rokitansky-Aschoff sinuses were present the predominant cell adjacent to the invaginated epithelial surface was the IgA-containing cell.

In some cases of chronic inflammation lymphoid

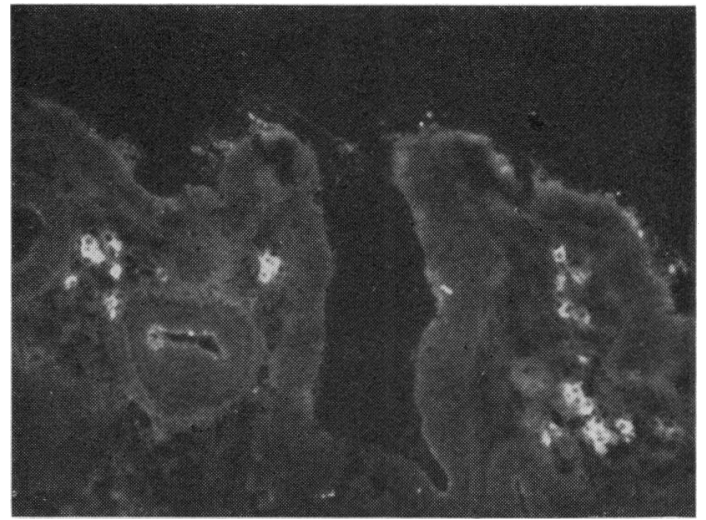

Fig. 1 Normal gall bladder mucosa after incubation with anti- $\operatorname{Ig} A$. A relatively small number of fluorescent mononuclear cells are present $(\times 90)$.

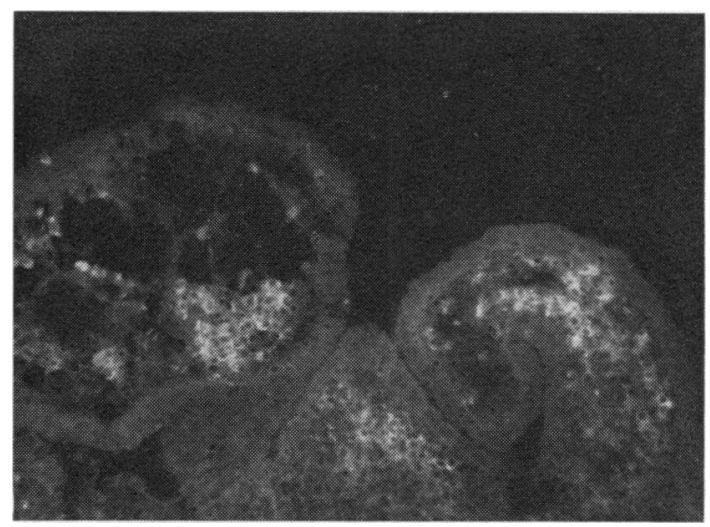

Fig. 2 A gall bladder showing a moderately severe chronic inflammation; view of the mucosa after incubation with anti-IgA. The number of fluorescent mononuclear cells is much higher than in the normal gall bladder $(\times 90)$.

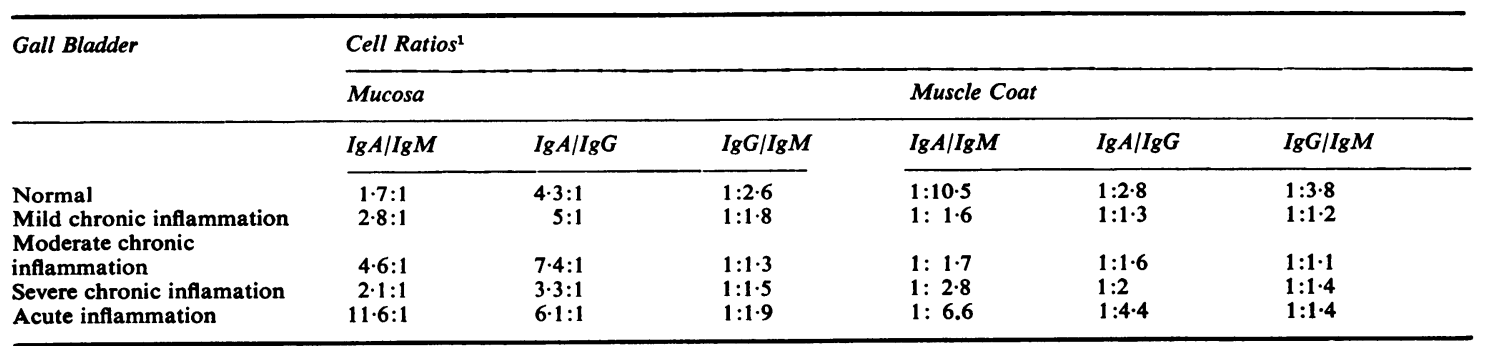

Table II Ratio of cells containing $\operatorname{Ig} A, \operatorname{IgG}$, and $\operatorname{Ig} M$ in the normal and abnormal gall bladder

${ }^{1}$ The figures denote the ratios of the mean numbers of specifically fluorescent cells per cubic millimetre of interstitial tissue. 


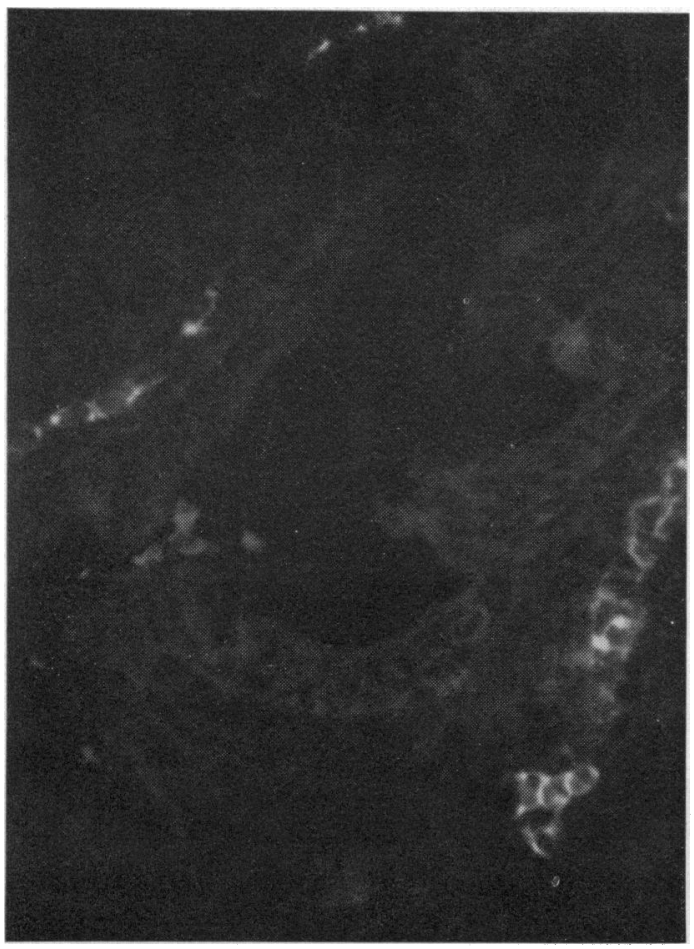

Fig. 3.

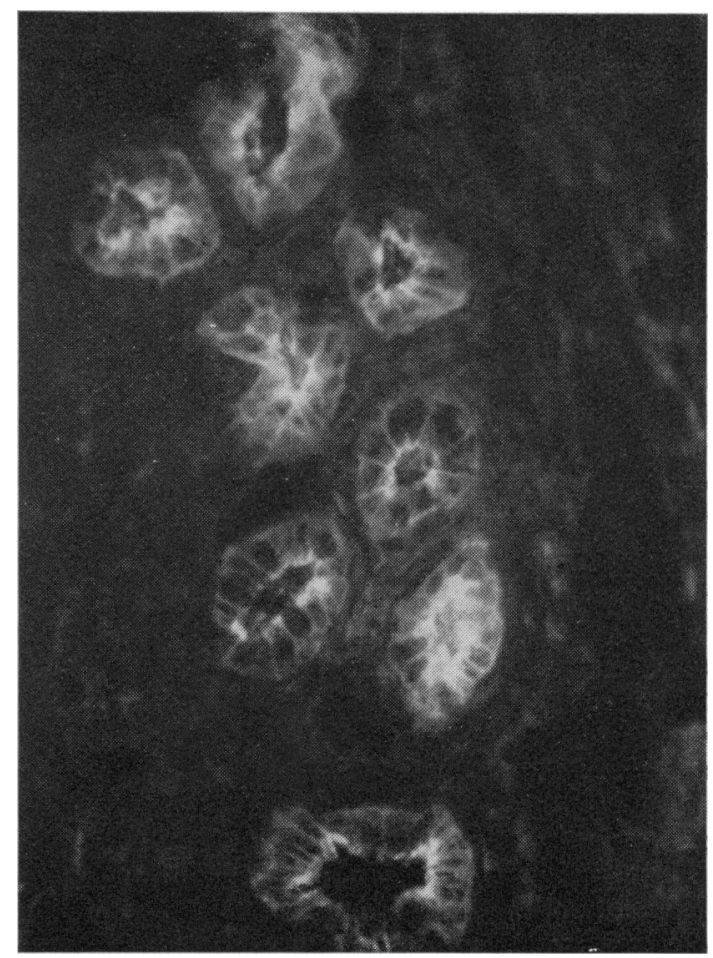

Fig. 4.

Fig. 3 Normal gall bladder epithelium after incubation with anti-IgA. There is no fluorescence in the epithelial layer $(\times 300)$.

Fig. 4 An area of intestinal metaplasia in a gall bladder after incubation with anti-IgA. There is striking fluorescence of the apical cytoplasm of the intercellular spaces $(\times 300)$.

follicles were present in the wall of the gall bladder. These showed intense fluorescence when tested against each of the specific antisera and there appeared to be approximately equal numbers of cells containing immunoglobulin. Where germinal centres were present these gave a negative reaction for IgA and IgG and showed only very slight cytoplasmic fluorescence when tested for IgM.

\section{Epithelial fluorescence}

Convincing epithelial fluorescence to the antisera was not seen in the majority of gall bladders (Fig. 3) though occasional non-specific fluorescence of the surface mucosa was seen when testing with antisera to IgA.

In those cases in which intestinal metaplasia of the epithelium was a prominent feature intense fluorescence of the apical cytoplasm, the luminal surface, and the epithelial intercellular spaces was seen in those areas of the mucosa showing metaplasia (Fig. 4) when tested with antisera to IgA: this fluorescence was not demonstrable in the nonmetaplastic mucosa of the same gall bladders.

\section{Discussion}

Immunoglobulin-containing cells are normally present in the human gall bladder. The figures obtained in this study for the number of such cells in the uninflamed organ should be treated with some caution for they are based on the study of only three gall bladders; attempts to obtain further normal gall bladders from necropsies showed that the degree of autolysis in such material invalidated any serious study.

Despite this limitation there can, nevertheless, be little doubt that the immunoglobulin-containing cell population of the normal gall bladder is much lower that that in any part of the normal intestine. In the mucosa the general pattern is, however, similar to that noted elsewhere in the body with a predominance of cells containing IgA; in the muscle 
coat IgM-containing cells predominate and the regular association of these cells with small blood vessels may indicate that they are derived from the circulating blood. Our findings relating to the distribution of IgA-containing cells in the gall bladder are similar to those reported by Tourville, Adler, Bienenstock, and Tomasi (1969) though, in contrast to our findings of a predominance of IgM-containing cells over IgG-containing cells in both mucosal and muscle layers, these workers found that cells containing IgG were more numerous in the mucosa than were those containing IgM; they did not, however, quantitate the cellular populations, and, as only two cases were studied, this discrepancy may represent a sampling difference which can only be resolved by the study of a much larger number of normal organs.

The local immunoglobulin-containing cells appear to participate in inflammatory disease of the gall bladder, and the principal initial response in cholecystitis appears to be a proliferation of IgAcontaining cells; in severe chronic inflammatory disease, however, the number of cells containing IgG and IgM rises proportionally more than does that of cells containing $\operatorname{IgA}$ and this may indicate a transition from a predominantly local immune defence reaction to one that is dependent upon bloodborne antibodies.

The stimulus, in chronic cholecystitis, for proliferation of $\operatorname{IgA}$-containing cells is uncertain. In the intestinal tract these cells are few in germ-free animals (Crabbé, Bazin, Eyssen, and Heremans, 1968) and hence it is thought that they proliferate in response to bacterial antigens. Chronic cholecystitis is often thought to be abacterial; the normal gall bladder is certainly sterile (Edlund, Mollstedt, and Ouchterlony, 1958) but several workers have found that bacteria can be cultured from the gall bladder wall in as many as $50 \%$ of cases of chronic cholecystitis without bile duct obstruction, this figure rising to $90 \%$ in cases with choledocholithiasis (Edlund et al, 1958; Flemma, Flint, Osterhout, and Shingleton, 1967). Our findings would possibly tend to substantiate these claims.

In this study no positive evidence was found to suggest that locally synthesized IgA is actually secreted into the bile. In the gut IgA can be demonstrated not only in the lamina propria but also in the intercellular spaces of the epithelium and in the apical cytoplasm of the epithelial cells (Gelzayd, Kraft, and Fitch, 1967). This has prompted the hypothesis that after synthesis of IgA as a 7S monomer in the lamina propria it subsequently passes through the intercellular spaces of the epithelium only to become arrested at the tight junction of the free margin of the epithelial cells; it is suggested that it then diffuses laterally into the apical margin of the epithelial cells from where it passes into the gut lumen (Tourville et al, 1969). At some stage during this transit the immunoglobulin becomes linked with secretory piece and is eventually secreted in an IIS form. This proposed mechanism of transepithelial transfer of IgA is still only a hypothesis but in the gall bladder IgA is not demonstrable in the intercellular spaces of the epithelium or in the apices of the epithelial cells (unless intestinal metaplasia is present).

Three possibilities must therefore be considered:

(1) The mechanism suggested for transepithelial transfer in the gut is correct and is of universal application.

(2) The suggested transfer mechanism is correct but is specific for the gut.

(3) The suggested transfer mechanism is incorrect.

If (1) is proved to be true then our results indicate that locally synthesized IgA is not secreted from the gall bladder into the bile unless intestinal metaplasia is present. If (2) or (3) is proven to be the case then the possibility of direct secretion of IgA into the bile by a quite different and as yet undetermined mechanism still exists.

If transfer of IgA across the biliary epithelium does not occur this is not due to any deficiency of secretory piece for this appears to be abundantly present in this site (Tourville et al, 1969). Secretory piece has not, however, been shown to be essential for transepithelial transfer and its definitive function remains unclear.

Despite our failure to demonstrate secretion of IgA by the gall bladder this substance is present in the bile in a concentration $(160 \mathrm{mg} \%)$ similar to that found in the small intestine (Tomasi, 1970). As the mean daily volume of bile in the normal adult is approximately 1 litre this would entail a daily production of biliary IgA in excess of $1.5 \mathrm{~g}$. It is difficult to explain this in terms of local synthesis within the biliary system for, even if transepithelial passage of locally produced IgA did occur in the gall bladder, the number of cells synthesizing this immunoglobulin is too small in the normal gall bladder to allow for their making any significant contribution to the total bile IgA. There is no evidence available that the liver is capable of synthesizing IgA and therefore the immunoglobulins in bile must be largely derived from either blood or the intestine. Keclik, Wolf, Felsenfeld, and Smetana (1970) noted a marked elevation of biliary immunoglobulins in experimental cholera infections in subhuman primates and thought that this excess was principally derived from circulating antibodies in the blood. In man the evidence to date points to a purely local production of secretory immuno- 
globulins but in pregnant cows colostral immunoglobulins are derived from the serum whilst in the newborn calf immunoglobulins are transported from serum to saliva, this transport system being highly selective for one immunoglobulin class (Sullivan, Prendergast, Antunes, Silverstein, and Tomasi, 1969). The possibility that human biliary immunoglobulins are similarly derived merits attention therefore, though most IgA in bile is in the IIS form; conceivably secretory piece is added to the $\operatorname{IgA}$ in the lumen of the biliary tract.

A further possibility to be considered is that there is some form of enterohepatic circulation of immunoglobulins. Bull, Bienenstock, and Tomasi (1971) perfused segments of isolated intestine and found considerable amounts of $\operatorname{IgA}$, admittedly in the $7 \mathrm{~S}$ form, in the venous return from the loop. Whether this indicates that in vivo immunoglobulins enter from the gut into the portal blood and whether, if this were the case, these subsequently enter the bile is conjectural.

We are grateful to $\mathrm{Mr} \mathbf{H}$. B. Torrance, $\mathrm{Mr} \mathrm{A} . \mathrm{R}$. Anscombe, and Mr N. C. Keddie for their cooperation in the obtaining of fresh material, and to $\mathrm{Mr}$ G. C. W. Humberstone for his assistance with the microphotography.

\section{References}

Brandtzaeg, P., Fjellanger, L., and Gjeruldsen, S. T. (1967). Localisasation of immunoglobulins in human nasal mucosa. Immunochemistry, 4, 57-60.
Bull, D. M., Bienenstock, J., and Tomasi, T. B., Jr. (1971). Studies on human intestinal immunoglobulin A. Gastroenterology, 60, 370-380.

Crabbe, P. A., Bazin, H., Eyssen, H., and Heremans, J. F. (1968). The normal microbial flora as a major stimulus for proliferation of plasma cells synthesising IgA in the gut. Int. Arch. Allergy, 34, 362-375.

Crabbe, P. A., Carbonara, A. O., and Heremans, J. F. (1965). The normal human intestinal mucosa as a major source of plasma cells containing A immunoglobulin. Lab. Invest., 14, 235-248.

Crabbé, P. A., and Heremans, J. F. (1960). The distribution of immunoglobulin-containing cells along the human gastrointestinal tract. Gastroenterology, 31, 305-316.

Edlund, Y. A., Mollstedt, B. O., and Ouchterlony, O. (1958). Bacteriological investigation of the biliary system and liver in biliary tract disease correlated to clinical date and microstructure of the gall bladder and liver. Acta chir. scand., 116, 461-470.

Elias, H., Hennig, A., and Elias, P. M. (1961). Some methods for the study of kidney structure. $Z$. wiss. Mikr., 65, 70-82.

Flemma, R. J., Flint, L. M., Osterhout, S., and Shingleton, W. W. (1967). Bacteriologic studies of biliary tract infection. Ann Surg., 166, 563-570.

Gelzayd, E. A., Kraft, S. C., and Fitch, F. W. (1967). Immunoglobulin A: localization in rectal mucosal epithelial cells. Science, 157, 930-931.

Keclik, M., Wolf, R. H., Felsenfeld, O., and Smetana, H. F. (1970). Immunoglobulins and antibodies in gallbladder bile. Amer. J. Gastroent., 54, 19-29.

Rossen, R. D., Morgan, C., Hsu, K. C., Butler, W. T., and Rose, H. M. (1968). Localisation of $11 \mathrm{~S}$ secretory IgA by immunofluorescence in tissues lining the oral and respiratory passages in man. J. Immunol., 100, 706-717.

Sullivan, A. L., Prendergrast, R. A., Antunes, L. J., Silverstein, A. M. and Tomasi, T. B. (1969). Characterisation of the serum and secretory immune systems of the cow and sheep. J. Immunol., 103, 334-344.

Tomasi, T. B., Jr. (1970). Structure and function of mucosal antibodies. Ann. Rev. Med., 21, 281-298.

Tomasi, T. B., Jr., and DeCoteau, E. (1970). Mucosal antibodies in respiratory and gastrointestinal disease. Advanc. intern. Med., $16,401-425$.

Tourville, D. R., Adler, R. H., Bienenstock, J., and Tomasi, T. B., Jr. (1969). The human secretory immunoglobulin system; immunohistological localisation of I $\gamma \mathrm{gA}$ secretory 'piece' and lactoferrin in normal human tissues. J. exp. Med., 129, 411-429. 